\title{
Finance, social value, and the rhetoric of GDP
}

\section{Jacob Assa}

New School for Social Research, USA

\begin{abstract}
The global financial crisis is usually seen as a failure of neoclassical economic theory and neoliberal policy, but it also represented an epistemological failure. Forecasters who missed the crisis neglected to include the financial sector in their models, while aggregate indicators such as GDP failed in spite (or perhaps because) of their heavy emphasis on financially driven growth. In contrast to both critics and proponents of GDP who see it as a purely statistical measure, this article argues that GDP is in fact a form of numerical rhetoric. Political messages in such estimates were explicit until the early twentieth century, but have since become implicit in hidden assumptions. To uncover the narratives built-in to GDP's view of finance, the article conducts a thought-experiment comparing GDP with two counterfactual indicators corresponding to historical views of finance as either non-productive or an actual cost to society. The analysis shows how changing this single assumption leads to very different narratives regarding the class-balance of workers vs. capitalists, the relative importance of consumption, and the extent of space that exists for public policy to influence the economy. The article concludes with some thoughts on making the implicit assumptions in GDP explicit, and opening up the debate to the broader public in a transparent way.
\end{abstract}

\section{Keywords}

National accounts, finance, GDP, social value, distribution, rhetoric

\section{Introduction: The financial crisis as an epistemic failure}

\footnotetext{
There is no such thing, per se, as national income, aside from a theory of how to combine elements in the economy into this special number. (Minsky, 1986: 3)

If banking had been subtracted from GDP, rather than added to it, as Kuznets had proposed, it is plausible to speculate that the financial crisis would never have happened. (Pilling, 2014: para. 18)
}

\section{Corresponding author:}

Jacob Assa, New School for Social Research, 6 East 16th Street, New York, NY 10003, USA.

Email: assaj401@newschool.edu 
The idea that the global financial crisis of 2007-8 and the ensuing Great Recession caught policymakers, economists and financial market experts by surprise has led to much soulsearching. The crisis is often portrayed as a failure of neoclassical economic theory, epitomized by the famous admission from former Federal Reserve chairman Alan Greenspan, in his testimony to Congress: "[the] modern risk-management paradigm held sway for decades ... [this] whole intellectual edifice, however, collapsed in the summer of last year" (quoted in Andrews, 2008: para. 11). Accompanying this theoretical crisis was a realization that the hands-off neoliberal policies applied to the financial sector in the 1990s and 2000s may have been naïve. As Greenspan again put it, "Those of us who have looked to the self-interest of lending institutions to protect shareholders' equity, myself included, are in a state of shocked disbelief" (quoted in Andrews, 2008: para. 3).

These views on the failure of both theory and policy have been echoed numerous times since Greenspan's testimony, and represent an ontological crisis that could be summed up in the statement 'the financial system does not work the way we thought'. The level of shock and disbelief is embarrassing, given that many heterodox scholars not only warned of an impending crisis but were very precise in terms of how (household debt) and when (around 2006-8) it would happen (e.g. Bezemer, 2010; Galbraith, 2009). But beyond dispelling the myth that "no one saw this coming', the existence of such unheeded warnings can teach us something about the contrasting views of finance held in our society. In other words, instead of letting a good crisis go to waste (which Winston Churchill famously advised against), one might also identify in it an epistemological failure on the part of dominant swaths of society (the academic mainstream, leading political parties in countries such as the US and the UK, and the media).

The crisis, and the fact that it shocked many experts, revealed a consensus narrative of finance that not only was unrealistic but also self-contradictory. On the one hand, standard economic theory portrayed financial institutions, actors and motives as highly beneficial to society as well as extremely efficient, a view that in turn undergirded policies of deregulation and an insufficient monitoring of what was going on in the financial sector. On the other hand, applied economists (such as those in central banks and other regulatory institutions) actively excluded financial markets, banks and debt from their forecasting models and focused only on the 'real' (i.e. non-financial) economy. Likewise, official government statisticians constructing aggregates such as Gross Domestic Product (GDP) did not (and still do not) track the huge flows of credit swirling around, capturing only interest and fee payments as the footprints of the financial sector. The rich data on actual debt flows and stocks were always available in balance sheets and flow-of-funds accounts, but very few people looked at them. As it happens, those who did were the same people who predicted the crisis, which was no coincidence (Bezemer, 2010).

This means that while in theory, finance is considered to be one of the most important sectors of a modern economy, in practice it was treated as irrelevant when it came to monitoring and measuring its actual behaviour (notwithstanding occasional celebrations of stock market record highs). This narrative is not only schizophrenic, but may have contributed to groupthink and the inability of most decision makers to foresee any trouble. The quote from the Financial Times in the epigraph to this article suggests that headline figures such as GDP were telling an overly optimistic and thus misleading story in the lead-up to the crisis, precisely because of their blindness to private debt flows and banks' balance sheets (information which policymakers, the media and regulators do not consult). ${ }^{1}$ This can be seen in the left-hand side panel of Figure 1 below, where a forecast of employment for the period 1995-2014, based on 
GDP data between 1970-1974, would have shown a booming economy. By contrast, the righthand side panel shows a counterfactual measure (FGDP) that treats finance as a cost to the rest of the economy. The latter looks, in hindsight, to be a much better predictor of the crisis.

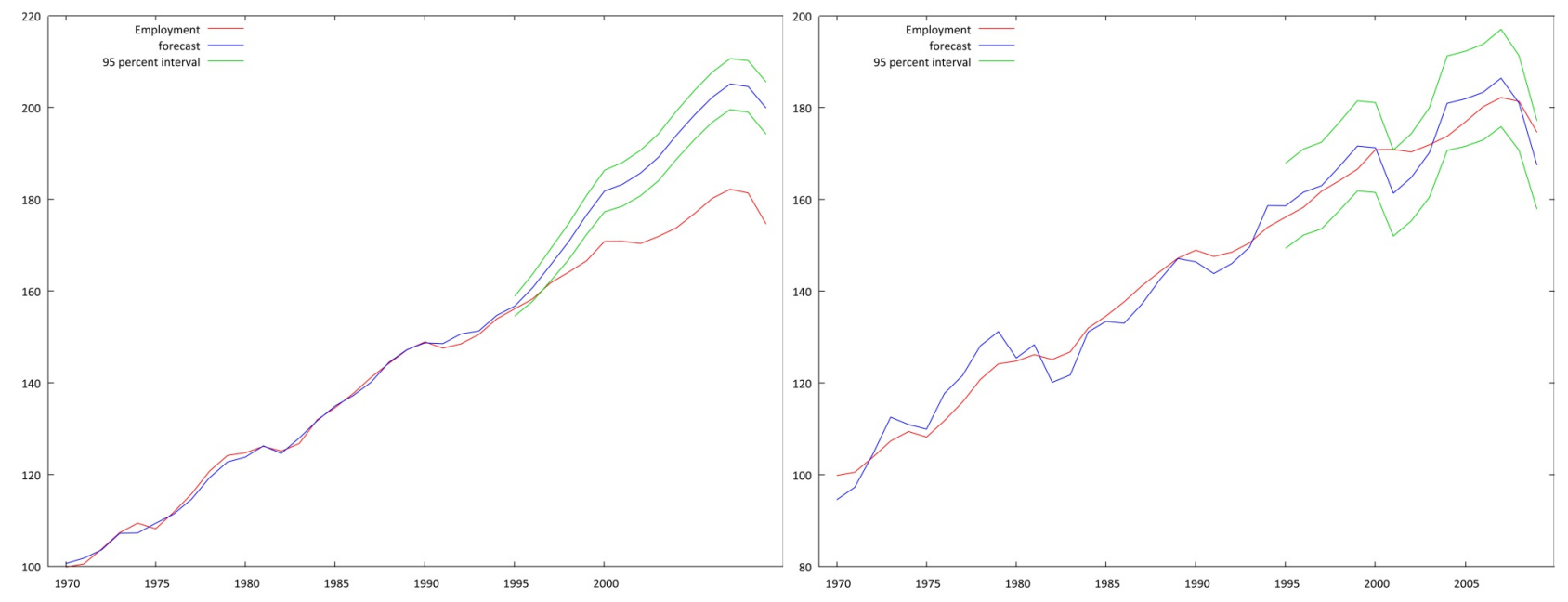

Figure 1. Forecasts of employment using US data from 1970-1994 (GDP on left/FGDP on right). Source: Assa, 2016: 83.

GDP's importance stems from its ubiquity in modern societies, appearing daily in news, political debates, inter-country comparisons and even international agreements (such as the EU accession rules on levels of debt and deficits, which are defined in terms of percentage of GDP thresholds). However, both proponents and critics of GDP often misunderstand it. The former, as well as most of the general public, consider it an objective statistic, based on a positivist approach and a purely technical methodology. For example, when we read something like 'the economy grew by $2.8 \%$ this quarter, exceeding forecasters' expectations', real GDP growth is implied as the standard measuring rod for the economy, implicitly analogous to the statement 'the country experienced a heat wave of 40 degrees Celsius', which describes an atmospheric measurement.

Critics of GDP, by contrast, believe that while it is supposed to measure welfare or progress, it is flawed as it has not caught up with (a post-modern view of) the times. If only GDP were reformed, or so goes the argument, to include some additional desired components (e.g. unpaid care work) and exclude others (such as the costs of pollution or military expenditures), then all would be well. This view is based on a normative approach to social accounting, where constructs like GDP are perceived to represent universal values, and their flaws are attributable mainly to a dissonance between official statistics as a relic of materialist society and the post-consumerist ideal of the good life.

This normative approach has recently been on the rise as evident in a flurry of general audience books published in the last decade (e.g. Stiglitz et al., 2010; Fleurbaey and Blanchet, 2013; Fioramonti, 2013, Coyle, 2014; Philipsen, 2015; Lepenies, 2016). Such books focus on GDP's shortcomings and describe various alternatives. Their foray into the history of national accounting focuses on the twentieth century, with only passing references (if any) to the 250 years preceding it (stretching back to William Petty's Political Arithmetick in 1676, the first known attempt to measure the wealth of nations).

Is GDP then an objective measure of economic production, a normative indicator of welfare, a hybrid of both, or something else entirely? How does the changing representation of 
finance in GDP affect its visibility in society, and how is this very process shaped by norms and values regarding the social roles of finance?

\section{From political arithmetic to numerical rhetoric}

Answering the first question ('What is GDP?') turns out to be less simple than the two polarized views caricatured above suggest. On the surface, the mainstream view of GDP as an objective measurement of economic performance seems to conflict with the critics' view of it as a flawed indicator of progress. At their core, however, both views share the implicit assumption that there is ultimately one right answer to the question of what GDP should be.

Other approaches consider GDP to be more historically and socially contingent. MitraKhan (2011) and Coyle (2014) suggest that GDP is the economy, i.e. the latest consensus definition of what it is in reality. In this view, rather than tracking how well the economy is doing, GDP really only delineates its structure and boundaries as per the beliefs of a particular society. Christophers (2011) goes a step further and characterizes national accounting, the system of which GDP is the best-known aggregate, as a social construct based on a technopolitical process. He describes, for example, how the 1968 revision to the System of National Accounts (SNA) made finance productive by reclassifying banks' net interest income, previously ignored as mere transfers, as part of value-added. The decision was made not by economists or financial engineers, but rather by the United Nations Statistical Commission, comprised of chief government statisticians from various countries. Similarly, the 2008 SNA reclassified Research and Development $(R \& D)$ expenditures from intermediate consumption (deducted from GDP) to fixed investment (added to GDP). When the US adopted this standard in 2013, its GDP increased overnight by $\$ 560$ billion, more than the entire Swedish GDP for that year (Economist Intelligence Unit, 2013).

Extending Christophers' approach, national accounting can be thought of as a form of numerical rhetoric, in the sense that it has always been used to convey different narratives about various economic, social and political issues. While the term 'rhetoric' is often used in the derogatory sense, implying empty talk, here it is used in line with McCloskey's (1983) work on the rhetoric of economics. In that article and a subsequent book, McCloskey employs a definition of rhetoric from Wayne Booth, as "the art of probing what men ought to believe, rather than proving what is true according to abstract methods" (Booth, 1974 [quoted in McCloskey, 1983: 482, emphasis added]). In other words, national accounting is a numerical form of the classical art of persuasion, intended to convince rather than to measure.

This idea was quite explicit in early examples of national income estimates (which are not discussed in most of the recent books on GDP mentioned above). For example, both William Petty and Gregory King in the seventeenth century used their estimates to demonstrate the relative economic strength of England vis-à-vis France or Holland at the time. Petty also relied on his calculations to argue that "Some kind of Taxes, and Publick Levies, may rather increase than diminish the Common-Wealth" (Petty, 1676: n.p.), while British Prime Minister William Pitt, proposing the first general income tax in Britain in 1798, estimated national income excluding labour income in his account, since he was arguing for exempting labour from the income tax. Benjamin Bell (in 1799 and 1802) prepared his estimates to refute Pitt's view, as well as to argue for a repeal of the Corn Laws.

In France, Pierre de Boisguilbert, lieutenant-governor of Rouen, estimated national income in 1697 and 1707 to advocate for repealing most taxes while imposing a low poll tax on all adults. As an ardent critic of the French government's mercantilist policies, he wrote a 
pamphlet entitled 'France ruined under Louis XIV' (for which he lost his post and was exiled to Southern France). Even Keynes, in his book How to Pay for the War (1940), provided estimates of British national income (none were included in his magnum opus, The General Theory), explicitly in order to convince the public and government of the need for deferring non-military consumption and directing resources to the war effort.

Subscribers to the Whig interpretation of history, however, would surely retort that these were understandable defects of early (read 'primitive') empirical forays, and that by the end of World War Two, the standardized and technically superior measure of GDP was no longer a rhetorical device but rather an objective statistical indicator. ${ }^{2}$ This is, in fact, the position of Paul Studenski, the celebrated first historian of national accounting, who wrote the following about W.I. King's 1915 estimate of US national income:

King's was one of the last national income estimates in any country to combine the estimating task with economic politics. Nearly all subsequent national income estimators limited themselves to the preparation of estimates, leaving the task of social, economic and political interpretation of their figures to other individuals. (Studenski, 1958: 143-44)

This view mistakes a change in the institutional setting of national accounting (from individual compilers to national governments and later international organizations) for a change in purpose and content. The two examples mentioned above - of how finance and R\&D were recently reclassified - have in fact had dramatic consequences on the social perception of these industries, despite the absence of an explicit policy interpretation. As Christophers (2011) explains, bringing banking within the production boundary of GDP solved an embarrassing situation wherein, when measured like other sectors, banking had often showed a loss rather than a profit before that point. Presenting $R \& D$ as investment rather than an intermediate cost likewise gave advanced countries a lead in the global economic race, reminiscent of the days of Petty and King. Not only did the change elevate R\&D to a productive activity in its own right, but it also had the effect of "reinforcing America's status as the world's largest economy and opening up a bit more breathing space over fast-closing China" (Economist Intelligence Unit, 2013: n.p.). Australia switched to SNA 2008 in 2009, "leapfrogging Canada in the OECD's country rankings of GDP per person" (The Economist, 2013: 64). ${ }^{3}$

It is true, however, that while this numerical rhetoric was explicit in the early centuries of political arithmetic, it became more hidden and implicit in what came to be known as "national accounting' after World War Two. Partly as a result of these calculations now being the official duty of governments (rather than the work of maverick intellectuals speaking their mind), and partly since 'economics' was now considered a science (in contrast with the more polemic discipline of political economy), economic statistics were presented from the mid-twentieth century onwards not with policy interpretations and prescriptions, but rather with 'methodological' or technical notes, detailing the various definitions and classifications used therein. The 2008 SNA, for example, is an 838-page tome that few economists, let alone policymakers, ever read or even know about.

This sanitized view of measuring the wealth of nations in our times creates the impression that GDP and other macroeconomic aggregates are 'data', i.e. objective statistical measurements (albeit more complicated than, say, the rate of unemployment), which can be contrasted with theory- and value-laden formal economic models. By this logic, there is no room for politics in their construction. 
This dichotomy between models and data is false, however, especially when it comes to complex accounting systems such as the national income and product accounts. A more accurate classification would involve a spectrum from explicit models (such as those used by central banks for forecasting) through implicit models (e.g. national accounting aggregates) to measured data (such as the unemployment rate). Explicit models have accounting identities plus behavioural equations, since they attempt to explain causality. At the other extreme, measured data involve straightforward observations and calculations. National accounting systems are a hybrid - they can be thought of as implicit models (or put another way, modelled data) rather than purely statistical constructs. They have accounting identities but no behavioural equations, as they describe relationships rather than explain causality. They thus fall somewhere in the middle of the spectrum as shown in Figure 2.

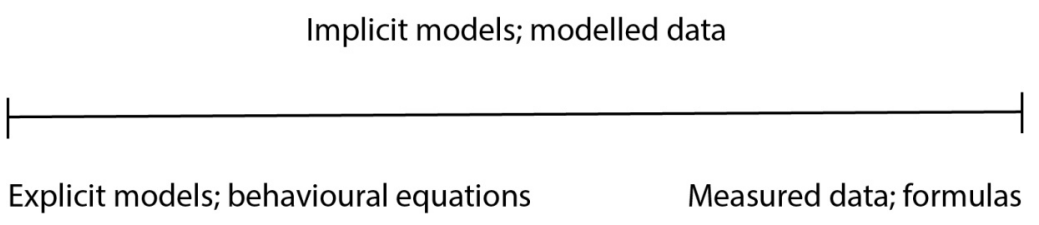

Figure 2. A three-tier taxonomy of the spectrum from data to models. Source: Author's own.

A concrete example of this taxonomy relating to finance would consider financial profits in each year (e.g. $\$ 1,000,000$ ) as objectively measured data; the share of these profits in GDP based on the assumption of whether finance is productive, neutral or extractive (implicit model); and a forecast of future profits based on several explanatory variables (explicit model).

\section{The rhetoric of finance}

Turning to the second of my questions posed earlier, if GDP is one form of numerical rhetoric (business accounting being another), then where is 'finance' in this form of communication? As the structure of GDP is socially, historically and politically contingent, so too is the representation of finance in it.

Before the end of the nineteenth century, banking and finance were not seen as part of the economy and consequently were left out of national income estimates. Thus, while Marx considered finance to be 'fictitious capital' that took from produced value rather than added to it, income estimates of the time did not show banking activities one way or another. Even Hilferding's (1910) Finance Capital, which considered that first era of financialization as the most advanced form of capitalism, did not have an effect on the representation of finance in social accounting.

Starting in the 1930s, finance was incorporated into GDP but only through the inclusion of banking fee-revenues in the accounts, leading to the banking problem mentioned above. Beginning with the 1968 SNA, however, and accelerating afterwards, finance's role in economy and society was represented with increasing importance for two distinct reasons. First, there was the qualitative change mentioned above, whereby the growing interest revenues of banks were reclassified from unproductive transfers to remuneration for productive (and hence socially useful) services, i.e. intermediation between savers and investors. This changed banking's economic footprint from mostly negligible (and occasionally negative) to positive through the net-interest imputation mentioned above. 
Second, there was exponential growth in the fees charged by banks such that by the first decade of the twenty-first century, finance thus represented constituted around 20\% of GDP in the US and UK, and over $10 \%$ in many other developed countries. ${ }^{4}$ Combined, these qualitative and quantitative changes constitute what I have termed a 'financialization of GDP' (Assa, 2015; 2016). This phrase echoes Epstein's (2005) seminal definition of financialization as the growing importance of financial motives and activities in the economy. The application of the concept to GDP simply refers to the increasing importance given to the financial sector in this socially constructed measure (both qualitatively and quantitatively as explained above), mirroring the increased weight of finance in terms of total profits, as well as its heightened political leverage in capitals such as London and Washington, DC.

This metamorphosis of the representation of finance from a negligent part of the economy to its single largest sector has had both proponents and critics. The CEO of Goldman Sachs famously declared his employees to be the most productive in the world (see McCarthy 2010: para. 3). This claim was only possible because finance appears as extremely productive in the national accounts, with an oversize output and very little increase in inputs (especially employment, see Assa, 2016). On the other hand, GDP's glorification of finance was criticized on theoretical and instrumental grounds (such as GDP's deteriorating performance as a leading indicator, as illustrated in Figure 1), and has led to the creation of several alternative indicators which either omit finance from GDP or even deduct it as an intermediate cost to the rest of the economy (Shaikh and Tonak, 1994; Basu and Foley, 2013; Assa, 2016).

However, one cannot turn back the clock to 1953, when financial incomes were accounted for as either negligible or negative contributions to the economy. For starters, at that time interest income accounted for the bulk of banks' revenues, whereas today financial fees dwarf banks' interest income in most countries (in the UK, for example, net interest income in 2005 was $£ 56$ billion compared with $£ 354$ billion for fee-based net revenues). There are, however, some precedents for removing various sectors from GDP. For example, in their celebrated paper 'Is growth obsolete?', Nordhaus and Tobin (1972) reclassify some consumer and government outlays as instrumental expenditures, that is, as intermediate rather than final. Thus they deduct the costs of commuting to work, police and sanitation services, and national defence from total (final) output.

In a similar vein, Shaikh and Tonak (1996: 2) reclassify military, bureaucratic and financial activities as social consumption rather than social wealth creation, arguing that such activities actually "use up wealth in the pursuit of protection, distribution and administration". Meanwhile, Basu and Foley (2013) exclude Finance, Insurance, and Real Estate (FIRE) sector incomes from GDP (creating a measure called Non-Financial Value-Added or NFVA) on empirical grounds, citing the same divergence of GDP and employment trends mentioned above. Their adjusted measure indeed tracks employment in the US far better than GDP.

Another proposed measure is Final Gross Domestic Product (FGDP), which deducts all fee-based income of financial institutions from GDP as an economic cost for other sectors, rather than merely excluding it as in Basu and Foley's case (on FGDP, see Assa, 2016). This measure performs better than either NFVA or GDP in the three dimensions measured above, that is, better correlation with employment trends, better correlation with median income, and a superior performance as a leading indicator (see Figure 1).

However, using the lens of numerical rhetoric to understand national accounting, we cannot conclude that GDP before 1968 was the correct measure, nor that any of the alternative measures mentioned above are superior to or more objective than GDP. On the contrary, as the Minsky quote in the epigraph suggests, national income is something constructed by choosing various elements in the economy. In addition to theory, however, 
there are values, social norms and conventions, as well as policies, which were explicit in early estimates of national income before the middle of the twentieth century, but since then have been rendered implicit in seemingly objective measures such as GDP.

\section{Narratives of finance implicit in GDP}

Beyond an overall increase in the importance of the FIRE sector in the narrative that is GDP, what are the implications of these changes for specific social classes, groups and sectors? Rather than exploring the aggregate implications of finance-dominated GDP for issues like jobless growth and the 'Great Moderation' storyline, the analysis below takes a more disaggregated approach, employing the device of a thought-experiment. Comparing GDP (which represents finance as highly productive) to two counterfactual measures that adopt rather different views on finance (finance as extractive and finance as neutral, respectively) will allow for a closer examination of the social implications associated with each different form of numerical rhetoric. Specifically, we are interested in how the three different social views of finance that are implicit in these aggregates affect our perception of different classes (workers vs. capitalists) as well as socio-economic groups (consumers, producers, and governments).

The reason this more disaggregated narrative is 'implicit' is that it cannot be seen directly in either GDP or the two alternative aggregates, requiring a detailed examination of inputoutput tables to see which part of financial 'value-added' goes to consumption, expenditure and investment, or to profits, wages and taxes. The public and even most economists are not well versed in this kind of empirical analysis (partly because such things are not taught anymore, even in graduate economics programs), and hence the resulting narratives about who the 'job-creators' really are and the dominance of the 'consumer-king', for example, go unchallenged. Simply looking at the share of consumption in GDP, for example, confirms the common wisdom that roughly $70 \%$ of aggregate demand in many advanced countries comes from the consumer. However, much of this is spent on paying banking fees. If these are left out or, alternatively, subtracted as social costs, the relative shares of consumption, investment and government spending change dramatically.

The three measures we compare are GDP; Non-Financial Value-Added, or NFGDP (Basu and Foley, 2013); and Final GDP, or FGDP (Assa, 2015, 2016). Table 2 sets out their respective treatments of finance, their rationales and their accounting implications

Table 1. Contrasting roles and weights of finance in three economic aggregates. Source: Author's own.

\begin{tabular}{|c|c|c|}
\hline Measure & Implied social role of finance & Weight of finance in total value-added \\
\hline GDP & Productive & 1 (positive) \\
NFGDP & Non-productive & 0 (neutral) \\
FGDP & Intermediate cost & -1 (negative) \\
\hline
\end{tabular}

As most people who have taken an introductory economics class will know, GDP can be broken down by expenditure $(\mathrm{Y}=\mathrm{C}+\mathrm{G}+\mathrm{I}+\mathrm{X}-\mathrm{M})$, where $\mathrm{Y}$ represents $\mathrm{GDP}$ by expenditure, $\mathrm{C}$ is consumption, $G$ is government expenditure, $I$ is investment, and $X$ and $M$ are exports and 
imports respectively. GDP is also the sum of incomes in society, adding up wages (and benefits), profits (including interest and dividends), and taxes.

In the first subsection, we examine the implications of the three alternative representations of finance for social groups such as consumers, firms, and governments, and in the next sub-section, the same analysis is performed by class (wage-earners, capitalists, and governments). This analysis will allow us to see how the different weights given to finance in GDP implicitly but clearly determine its characterization in social narratives.

\section{Of job creators and grateful workers}

Political and social discourse in favour of little or no regulation of capitalist economies often refers to the role of firms and entrepreneurs as 'job creators'. In this story, increasing taxes, regulations and other public constraints on business will harm everyone, as firms and markets need freedom to create jobs, which then benefit the working classes as well. This narrative is implicitly based on the centrality of profit to modern economies, and the logic that if taxes or regulations increase, profits and thus investment would fall, leading to more unemployment and a general decline in economic well-being.

Wages and profit shares have been relatively stable in the US over the past 30 years, as is shown in Figure 3 below. While the wage share declined slightly from $56 \%$ of aggregate income in 1987 to $53.8 \%$ in 2015, the profit share increased moderately from $37.5 \%$ to $39.7 \%$ (with taxes making up the remaining 6.7\% on average). On average, wages have been only 1.4 times greater than profits as a share of total income.

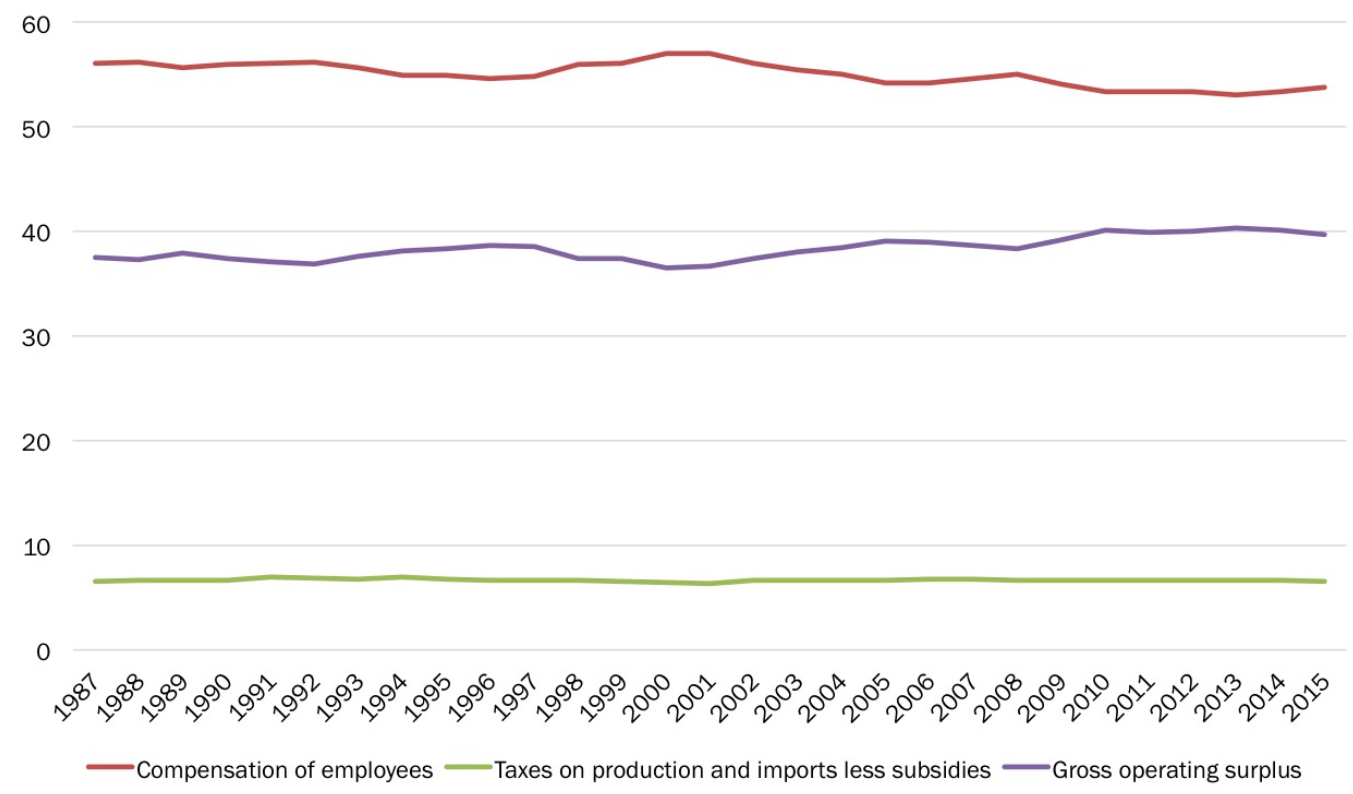

Figure 3. Wages, taxes and profits as shares of total US income, 1987-2015. Source: Author's calculations, based on National Income and Product Accounts from the Bureau of Economic Analysis <https://www.bea.gov/itable/index.cfm>.

This distribution, which implies a relatively similar weight for workers and capitalists in generating incomes, is premised on the large financial sector (including real estate and insurance) being counted as part of the productive economy. This sector is especially profitheavy, with $68 \%$ of its income over this period going to profits, compared to $23 \%$ going to 
wages (with taxes making up the remaining 9\% on average). Excluding or deducting finance from GDP (as in NFGDP and FGDP) changes the relative class structure of national income. Figure 4 below shows the average profit and wage shares in total income for all three measures side by side.

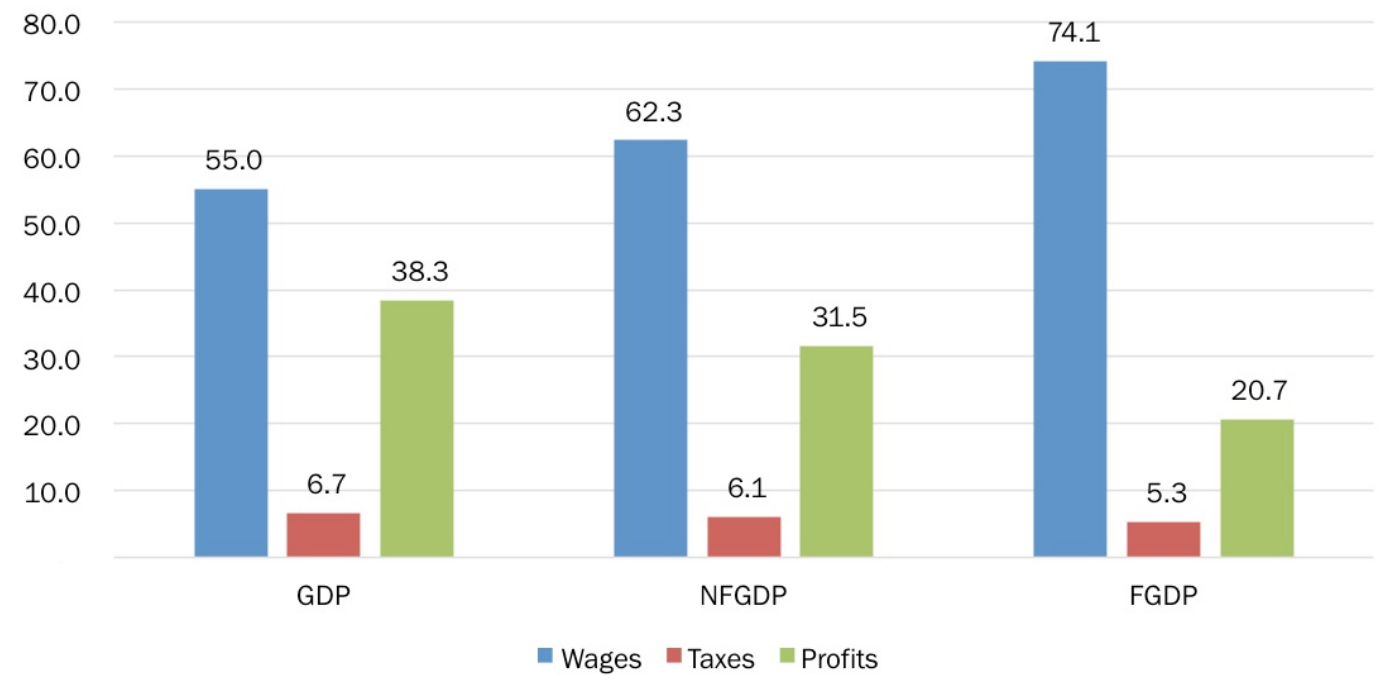

Figure 4. Respective shares of wages, taxes and profits in total US income based on three different assumptions. Source: Author's calculations, based on National Income and Product Accounts from the Bureau of Economic Analysis <https://www.bea.gov/itable/index.cfm>.

FGDP naturally shows the most extreme view, since if the FIRE sector is considered a cost to the real economy and deducted from GDP, subtracting its profit-heavy income lowers the overall profit share in GDP and increases the overall wage share. Thus wages account for $74 \%$ of all income in this scenario, and profits only $20.7 \%$. Taking the more conservative approach of NFGDP, which is similar to the original GDP definition from the 1930s (excluding rather than deducting finance), the share of wages is still nearly double that of profits in the economy, at $62.3 \%$ versus $31.5 \%$.

This comparison illuminates the fact that, in addition to the more obvious effect of different treatments of finance affecting the overall level of GDP and its growth rate (as shown in Assa, 2016), the implicit narrative in the income structure of GDP changes based on how the income of the FIRE sector is treated. The share of wages in total income has a direct and powerful implication for social discussions of the minimum wage, real wage stagnation vis-àvis productivity, as well as the question of who deserves government support in the form of tax cuts, subsidies and bailouts. If wage earners rather than entrepreneurs are the vast majority of income earners in the real economy, business-friendly policies (which are often inimical to wage growth) may not be in the best interest of the overall economy and thus society. The 'data' are thus not neutral, since different assumptions on what is included in the productive economy lead to different numbers, not only at the aggregate level but also for different income shares, with implicitly critical policy implications.

\section{King-consumer and hapless government}

Data on the distribution of expenditures by industry are sparser than data on income by industry, and are only available from 1997 onwards for the US. Nonetheless, it is useful to examine the implications of various representations of finance in GDP for narratives relating to 
the identity of the true 'engine' of economic growth. Normally this is assumed to be the consumer, an empirical implication of the dominant share of consumption in GDP, which is conveniently in line with neoclassical theory's emphasis on utility-maximizing households as the foundation for all consumption and production decisions (as well as the neoliberal policy of laissez-faire). Once again, however, this 'fact' depends on an implicit assumption of whether finance is productive, neutral, or a cost to the economy. Figure 5 shows the expenditure shares by different sectors according to GDP, based on the 'finance is productive' assumption.

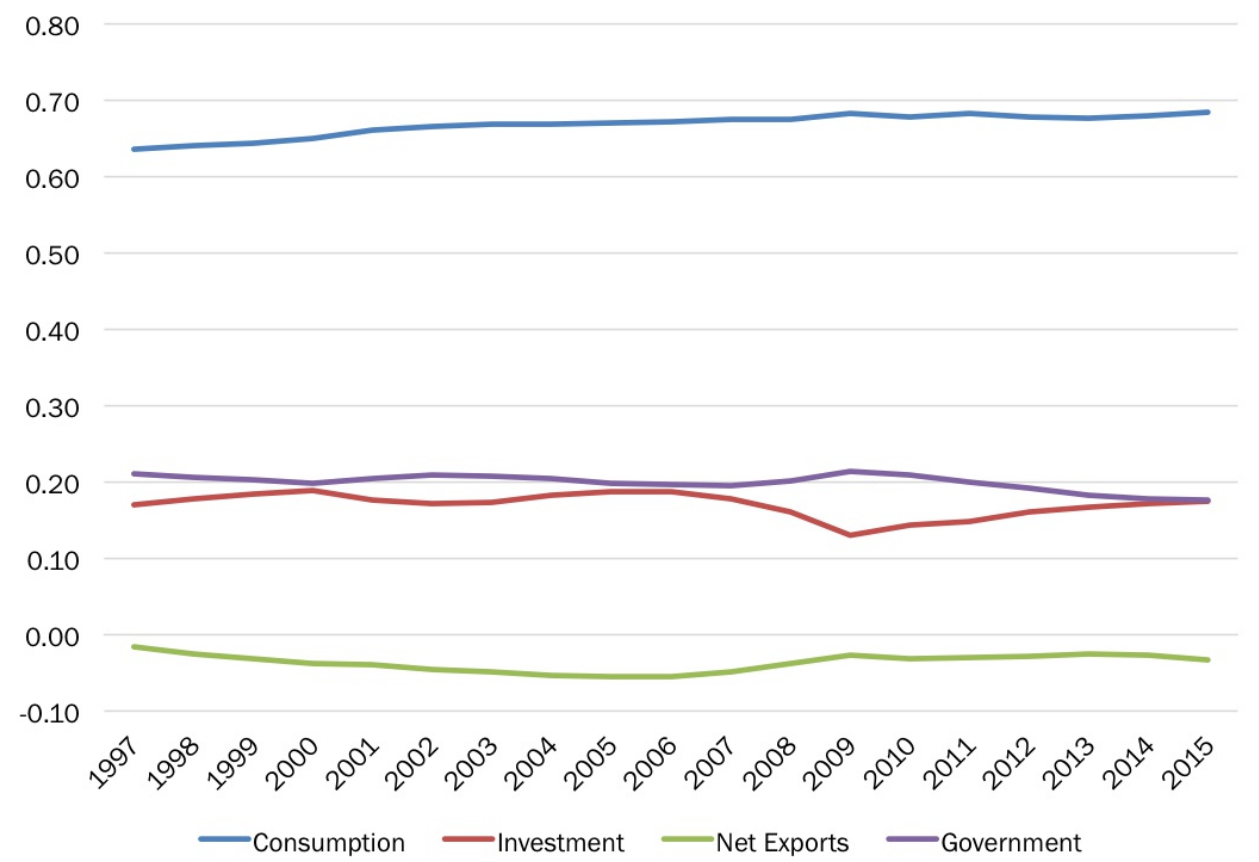

Figure 5. Respective shares of expenditures groups in total US output, 1997-2015.

Source: Author's calculations, based on Input-Output Tables from the Bureau of Economic Analysis < https://www.bea.gov/itable/index.cfm>.

Consumers, as seen through this narrative, are the undisputed leaders in generating aggregate demand for the economy, with private investment and government expenditure equally far behind. This lagging by both firm and government expenditure supports two parts of the narrative. First, both public spending and private investment are weak compared to the contribution of the consumer-led economy. This conveniently reduces the space for Keynesianstyle fiscal policies aimed at stimulating demand from either source of (real) investment. Secondly, the fact that the shares of government and investment spending in GDP are very similar to each other may further be presented as circumstantial evidence for the existence of a crowding-out effect, by which is meant that public spending displaces private investment, as the two compete for the same amount of limited resources (a fixed share of the pie so to speak).

Applying once more the idea of numerical rhetoric to this case, Figure 6 shows the alternative distribution by expenditure groups according to the three measures. 


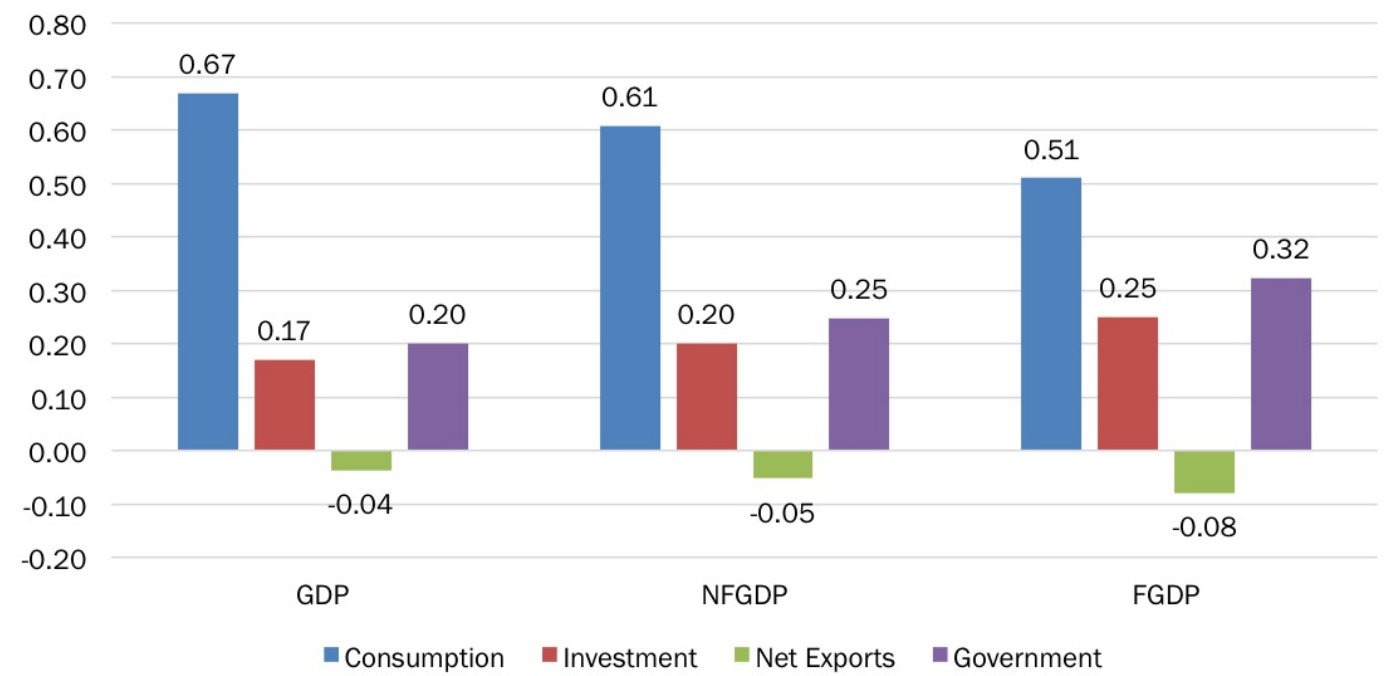

Figure 6. Respective shares of expenditures groups in total US output based on three different assumptions. Source: Author's calculations, based on Input-Output Tables from the Bureau of Economic Analysis <https://www.bea.gov/itable/index.cfm>.

The neutral-finance scenario (NFGDP) shows a somewhat smaller role for consumption and a slightly bigger role for investment and government expenditure. The gap between the latter two also increases in favour of the public sector. The finance-as-a-cost scenario (FGDP) more dramatically pulls public spending ahead of private investment, and the two combined now account for over $57 \%$ of aggregate demand, overtaking private consumption. This narrative implicitly suggests a more important role for demand-management policies from either the public or corporate sector.

\section{Conclusion: Towards transparency in narratives of finance}

This article has argued that both the advocates and critics of GDP mistakenly assume it to be purely a statistical measure, disagreeing mainly on whether it is measuring the 'right' thing, such as economic growth or human well-being, for example. But if GDP is a numerical form of rhetorical argument, then many of the recent critiques of it (such as that it doesn't account for pollution, paid care work, wars, happiness, and so on) are beside the point, since GDP is not a measure at all in the usual sense of the word. Rather, it is a particular mix of statistics, imputations, and implicit assumptions, which change from time to time, based on a society's views of what is productive, what is not, and what is rather an input to productive activities. If this argument is accepted, then the cottage industry in developing and proposing alternatives to GDP is barking up the wrong tree. Rather than a perfect or flawed measure, it is an implicit policy model of sorts. So, what to do?

In the short run, there are at least three options, none of which are mutually exclusive. One approach is to separate the statistical bits from the modelled parts that are intermingled in GDP. Basu and Foley's (2013) Narrow-Measured Value-Added (NMVA), for example, removes all industries for which value-added is imputed (finance, real estate, insurance, health, education and public administration). This measure tracks employment better than GDP, but unlike NFGDP and FGDP, it does not make any assumptions about what is productive or not (instead using an objective data-availability criterion for inclusion). 
Alternatively, one could follow the example of most of the economists who foresaw the crisis. As mentioned above, they didn't rely on GDP but looked at balance sheets, sectoral balances, and so on (Bezemer, 2010; Galbraith, 2009). However, this approach suffers from the difficulty in accessing and interpreting such complex datasets, which even most economists do not consult, let alone policymakers, the media or the general public. Part of GDP's success has arguably come from its parsimonious nature as a single number - in Lepenies' (2016) estimation, the 'most powerful number' - which reduces the enormous complexity of the economy down to a single figure. ${ }^{5}$

In the long run, however, finding alternatives to GDP is less important and probably less effective than enhancing transparency about what assumptions go into its construction. Amazingly, no graduate program in economics has a course on national accounting (such courses only exist in professional training and 'capacity building' programmes of national and international organizations, such as statistical offices, the World Bank, IMF, OECD, and so on). Adding such a course, informed by history and context rather than just technical details, would arguably reduce the gap between theory and data in the dismal science.

However, this education needs to go beyond economists' professional training, as the issues raised above concern the broader public including citizens, policymakers and journalists. If the debate on what is considered socially useful, economically productive, or environmentally sound is to go beyond technical discussions of experts and into the broader democratic discourse, the implicit rhetoric of GDP must be made explicit. The media could play an especially useful role in this case, as it has the potential to disseminate complex ideas in relatively jargon-free terms to the widest audience possible.

Another option is the inclusion of clear caveats whenever GDP figures are used, similar to the Surgeon General's mandatory warning included on every package of cigarettes sold in the US. To avoid giving the impression that GDP is 'data' like the unemployment rate (an imperfect yet much more transparent statistic), metadata statements on what industries are included and which are excluded would make the narrative clearer and more informative. To build on the illustrative example introduced earlier on, a more candid and accurate statement would be 'the economy grew by $2.8 \%$ this quarter, including the finance, real estate and insurance sectors. The non-financial economy, by contrast, grew only $1.4 \%$ over this period'. This practice actually already exists when it comes to reporting the rate of inflation, since the consumer price index (CPI) has several versions, including 'core' inflation (excluding the volatile prices of food and energy) and overall inflation.

While such steps may not immediately displace the dominance of GDP as the arbiter of public policy and market sentiment, they could open up the debate about such aggregate figures and help bring a much needed perspective to discussions regarding economic theory and policy. For example, the repeal of the US Glass-Steagall Act in 1999 (which had separated commercial and investment banking since the Great Depression) was based on a narrative of finance as a hyper-productive sector in the midst of the roaring 1990s. A similar story has prevented sufficient monitoring of financial innovations that were considered to be reducing risks in the lead-up to the global financial crisis. Some 'data' are neither given nor objective, and while they tell a quiet, barely audible narrative, they stealthily shape our view of the world. This view, in turn, conditions what we think is possible or effective in the realm of policy.

\section{Disclaimer}

The views expressed herein are those of the author and do not necessarily reflect the view of the United Nations. 


\section{Notes}

1. The US Federal Reserve and other central banks normally use equilibrium models such as DSGE, where no banking sector exists so a financial crisis is not even in the realm of possibilities. This is the case even after the crisis, with the exception of the Bank of England's recent stock-flow consistent analysis (see Burgess et al., 2016).

2. The Whig approach to history is characterized by its tendency "to emphasize certain principles of progress in the past and to produce a story which is the ratification if not the glorification of the present" (Butterfield, 1931: v).

3. This recent advantage to developed countries may be due to a shift in the responsibility for setting the SNA standard from the United Nations alone (as in 1953 and 1968), to the Inter-Secretariat Working Group on National Accounts (ISWGNA). The UN, with its universal membership and equal vote for each country, has been outnumbered since 1993 by the four other members of the ISWGNA - the European Union, the Organization for Economic Cooperation and Development, the IMF, and the World Bank - all of which are characterised by stronger membership or voting rights for rich countries.

4. These figures are based on the broad definition of finance used by Krippner (2005) as including finance, insurance and real estate.

5. The only other indicator with any measure of success approaching that of GDP has been the Human Development Index (HDI) produced by the United Nations Development Programme. With the HDI, however, the entire normative framework and all assumptions are clearly presented, avoiding any appearance of value-free measurement.

\section{References}

Andrews, E.L. (2008) Greenspan concedes error on regulation. The New York Times, 23 October. Available at: <http://www.nytimes.com/2008/10/24/business/economy/24panel.html>. Accessed 9 February 2018.

Assa, J. (2015) Gross domestic power: Geopolitical economy and the history of national accounts. In: Desai, R. and Zarembka, P. (eds.), Theoretical Engagements in Geopolitical Economy (Research in Political Economy Volume 30A). Emerald Group, 175-203.

Assa, J. (2016) The Financialization of GDP: Implications for Economic Theory and Policy. London: Routledge.

Booth, W.C. (1974) Modern Dogma and the Rhetoric of Assent. Chicago, IL: University of Chicago Press. Basu, D. and Foley, D.K. (2013) Dynamics of output and employment in the US economy. Cambridge Journal of Economics, 37(5): 1077-1106.

Bernanke, B.S. (2004) The great moderation. Remarks at the meetings of the Eastern Economic Association, Washington, DC, February 20. Available at:

<https://www.federalreserve.gov/boarddocs/speeches/2004/20040220/>. Accessed 5 February 2018.

Bezemer, D. (2010) Understanding financial crisis through accounting models. Accounting, Organizations and Society, 35(7): 676-688.

Burgess, S., Burrows, O., Godin, A., Kinsella, S. and Millard, S. (2016) A dynamic model of financial balances for the United Kingdom. Bank of England Working Paper No. 614. Available at: $<$ https://www.bankofengland.co.uk/working-paper/2016/a-dynamic-model-of-financial-balancesfor-the-uk>. Accessed 5 February 2018.

Butterfield, H. (1931) The Whig Interpretation of History. London: Bell.

Christophers, B. (2011) Making finance productive. Economy and Society, 40(1): 112-140. 
Coyle, D. (2014) GDP: A Brief but Affectionate History. Princeton, NJ: Princeton University Press.

Economist Intelligence Unit (2013) New data reshape picture of US economy. 1 August.

Economist, The (2013). Boundary problems: America has changed the way it measures GDP. Free

Exchange, 3 August. Available at: < https://www.economist.com/news/finance-and-

economics/21582498-america-has-changed-way-it-measures-gdp-boundary-problems>. Accessed

9 February 2018.

Epstein, G.A. (2005) Financialization and the World Economy. Cheltenham: Edward Elgar.

Galbraith, J.K. (2012) Who are these economists, anyway? In: Papadimitriou, D.B. and Zezza, G. (eds.)

Contributions in Stock-flow Modelling. London: Palgrave Macmillan, 63-75.

Fioramonti, D.L. (2013) Gross Domestic Problem: The Politics Behind the World's Most Powerful Number. London: Zed Books.

Fleurbaey, M. and Blanchet, D. (2013) Beyond GDP: Measuring Welfare and Assessing Sustainability. Oxford: Oxford University Press.

Hilferding, R. (1981) Finance Capital: A Study of the Latest Phase of Capitalist Development. London: Routledge.

Keynes, J.M. (1940) How to Pay for the War: A Radical Plan for the Chancellor of the Exchequer. London: MacMillan and Co.

Krippner, G.R. (2005) The financialization of the American economy. Socio-Economic Review, 3(2): 173208.

Lepenies, P. (2016) Why GDP? Project Syndicate, 16 August. Available at: <https://www.projectsyndicate.org/commentary/why-gdp-by-philipp-lepenies-2016-08>. Accessed 5 February 2018.

Minsky, H.P. (1986) Stabilizing an Unstable Economy. New York, NY: McGraw-Hill.

McCarthy, R. (2010) Goldman Sachs CEO Lloyd Blankfein: Our employees are among the most productive in the world. The Huffington Post, 18 March. Available at: <http://www.huffingtonpost.co.uk/entry/goldman-sachs-ceo-lloyd-b_n_353504>. Accessed 5 February 2018.

McCloskey, D.N. (1983) The rhetoric of economics. Journal of Economic Literature, 21(2): 481-517.

Mitra-Khan, B.H. (2011). Redefining the Economy: How the 'Economy' was Invented 1620. Unpublished doctoral thesis, City University London. Available at: <http://openaccess.city.ac.uk/1276>. Accessed 9 February 2018.

Nordhaus, W.D. and Tobin, J. (1972) Is growth obsolete? In: Economic Research: Retrospect and Prospect, Volume 5, Economic Growth. Cambridge, MA: NBER, 1-80.

Petty, W. (1676) Essays on Mankind and Political Arithmetic. Available at: <https://www.gutenberg.org/files/5619/5619-h/5619-h.htm>. Accessed 10 January 2018.

Philipsen, D. (2015) The Little Big Number: How GDP Came to Rule the World and What to Do About It. Princeton, NJ: Princeton University Press.

Pilling, D. (2014) Has GDP outgrown its use? The Financial Times, 4 July. Available at: <https://www.ft.com/content/dd2ec158-023d-11e4-ab5b-00144feab7de>. Accessed 9 February 2018.

Shaikh, A.M. and Tonak, E.A. (1996) Measuring the Wealth of Nations: The Political Economy of National Accounts. Cambridge: Cambridge University Press.

Stiglitz, J.E., Sen, A., and Fitoussi, J.P. (2010) Mismeasuring Our Lives: Why GDP Doesn't Add Up. New York, NY: The New Press.

Studenski, P. (1958) The Income of Nations: Theory, Measurement, and Analysis. New York, NY: New York University Press. 